\title{
STUDIES ON THE INHIBITION OF THE APPEARANCE OF TIE \\ C.R.P. AND AMINO-ACIDS IN THE PERILYMPH ON THE PALATAL IRRITATION OF GUINEA PIG.
}

By

\author{
DaIICHIRO USUT
}

From the Department of Oto-Rhino-Laryngology, School of Medicine Keio University (Director: Prof. Y. Suzuki)

Animal experimentation have shown that autonomic nervous system played an inportant role in the appearances of free amino acids and C.R.P. (L.G. Chevance, 1957. Y. Sakamoto 1963.) in perilymph when diluted croton oil was injected into guinea pig's palate where autonomic nerve was well innervated.

The author's methods of animal experimentations were as follows;

1) The alternation of the appearanecs of aminoacids and C.R.P. in perilymph were observed after intra-muscular injections of adrenalin, pilocarpine snd nicotinic acid.

a) Adrenalin: C.R.P. was not seen markedly.

b/ Pilocarpine : C.R.P. was seen in perilymph, serum and liquor.

c) Nicotinic acid: Almost the same aminoacids of palatal irritation group were seen in per. jlymph.

2) The appearances of amino acids and C.R.P. on palatal irritation were inhibited by intra-muscular injection of Hexamethonium bromide, but not by Chlorpromazine of the autonomic nerve blocking agents.

3) C.R.P. was seen in serum, liquor for a short period during anaphylactic or histamin shock of guinea pig.

4) Cochlear blood-circulation of guinea pig was directly observed through Ultropaak-microscope.

\section{モルモツトロ蓋刺激時, 外リンパ液遊離アミノ酸及び C.R.P.の出現阻止に関する研究}

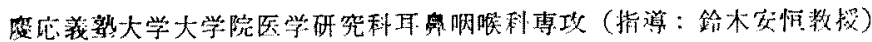

$$
\underbrace{}_{3} \text { 井 大我郎 }
$$

\section{第【音 緒志

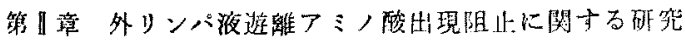 \\ 第 節 検查材料夰びに方法

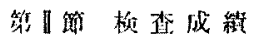 \\ 第凹筑䌊括业びに考敃 \\ 第 $N$ 筇

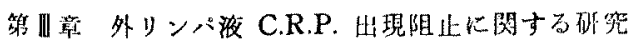 \\ 第|简 フドレナリン、ピロカルピン活射㭙における} C.R.P.
第 1 项 挨查材料亚びに力立

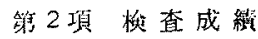

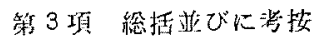

第』節 Hexamethonium bromide 投与比占る

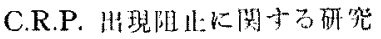

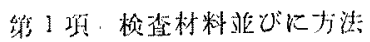

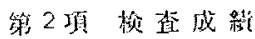

第3 项 秎括及び洘技

第W等 アナフイラキシーショック惹起㭙に和ける外り

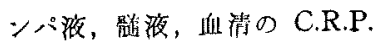




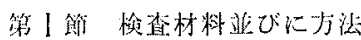

第 I節 検查成躃

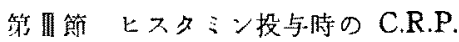

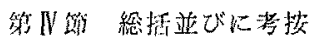

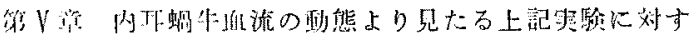
万考察

第】節 检查材料道びに方法

第 1節 检查成維

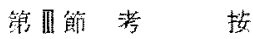

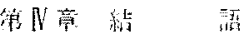

结考交献

\section{第 I 章 緒言}

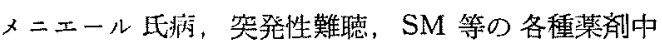
毒，その他样々な内耳疾患の病因は，近年の目覚しい笑 験及び臨床医学の発展により，次第に解明さ机てさた が，未だに多くの疑間点が残されており，しかもごく一 部の内耳疾患を除いては，暗中模䨋の実情である，各種

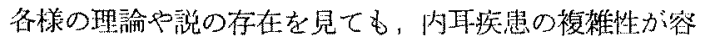

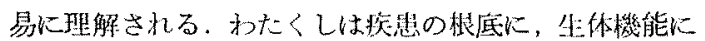
大きな役割を演してている上考えられる自律神経系を想定

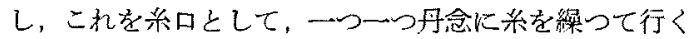
と，これら疾患の相当な部分が明確にしらるのではない か，といら教えのもとに，以下の契験を行つた。既に鈴

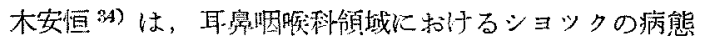
を研究中，ショック上いら動的要化を一つの函数と考を るとき，この圂数は，非沁に多くの贷数によつて定まる ものであるが，この变数中，時間的に最も早く彇き，そ れ故に一番雨大な影響を有するものは，植物神経である

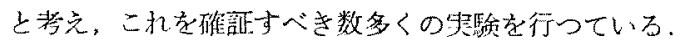

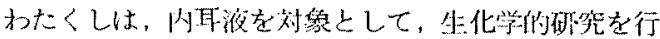

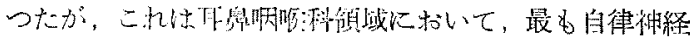
銷乱の影響を受け㚙く、往つて，その变動を捕えるこ之 で，鼠も急淁深いの市，内耳であると考えたからであ

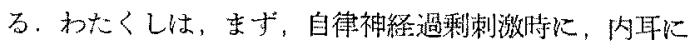

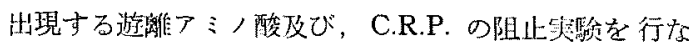
い, 次いで，動物フナフイラキシーショック掯の内耳

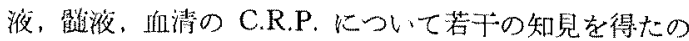
で、晁告する。

\section{第 II 章 外リンパ液遊離アミノ酸,} 出現阻止に関する研究

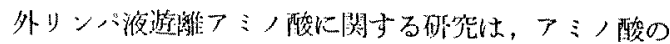
数が多いため，离传の分析技街が要求されること，及 び内推採取が困難であること等の理的で，最近迄，
西要な都告はなされていない、しかし，1950知に至り J.G. Waltner ${ }^{51)}$, S. Raymond $x^{3}, x= \pm ー ル$ 氏病患 者の内耳液をスペクトルで分析したのを契機として，吉 川 50) の家承及び犬 (1955)，松生 ${ }^{19)}$ の一次元ぺーバー クロマトグラフ法によるモルモットの内耳液の分析的 研究 (1957) が行われた。更に L.C. Chevance 2)429) (1957), 坂本 ${ }^{36)}$ (1963) K至り，分析技術も進歩し，二 次元ペーパークロマトグラフ法により，正常外リンパ渡 中に 7 種のアミノ酸, 即ら，ザルミン，アラニン、ス

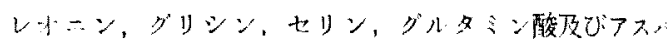

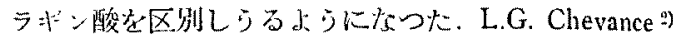

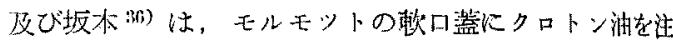
射し，いわゆるReilly 29) の過剩刺激湴侯群を生ぜしめ， この刺激によつて、正常時には見られない4種の遊離つ ミノ酸，即ち，リジン，フルギニン，上スチヂンといら デフミノ酸と，唯一のS基を有するチステイン酸が新た に出現することを見出し，この出現に，自律神経系の中 尔を推定した，口蓋の自律神絽を刺激することにより，

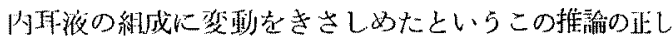
さを証明するため，ここに，わたくしは，以前に Reilly 現象の阻止笑駼で，数多くの成功 ${ }^{2)}{ }^{49}$ が得克られて いる自律神絽遮断剂の Chlorpromazine ${ }^{15)}$ を，次いて Hexamethonium bromide $\left(\mathrm{C}_{0}\right)$ を摸与して，ての阻此 效果を検索した。

第 I 節 梌查枋料並びに方洁

檕口盖のクロトン沺に上る刺激法は，坂末 ${ }^{36)}$ の方法 に基づいて行つた。

250 400gr の健康，焳性，成熱アルビノモルモット 艺用い，正円笖より毛細管ピペットにて啋取した外リン ハ液を10开分 pool して1回の声駼に供した. Chlorpromazine 投 5.21 .14 , pro $\mathrm{kg}, 1 \mathrm{mg}, 5 \mathrm{mg}, 10 \mathrm{mg}, 15 \mathrm{mg}$,

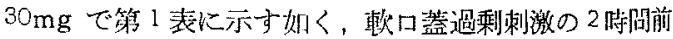
及び3時間前に分割摸与し，最終注射之同時に，動物の

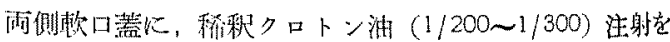
行つた。

Hexamethonium bromide $\left(\mathrm{C}_{6}\right)$ の投与法は，総量

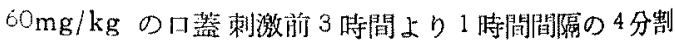
投与，及び $30 \mathrm{mg} / \mathrm{kg}$ の3 分割投与を武みた

第節 梌查成維

以上の綝果投与㭙において，外

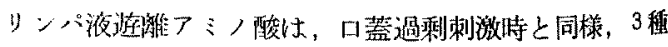
のナ゙アミノ酸に， $\mathrm{S}$ 基を有するシステイン酸の出現が 見られ，この贸験範囲内では，異常アミノ酸の出琴を全 


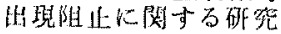

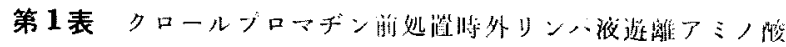

\begin{tabular}{|c|c|c|c|c|c|c|c|c|c|c|c|c|c|c|c|}
\hline $\begin{array}{l}\text { 实 } \\
\text { 駩 }\end{array}$ & 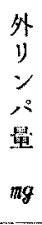 & $\begin{array}{l}\mathscr{7} \\
\text { ル } \\
\text { タ } \\
\vdots \\
\text { ン }\end{array}$ & ン & $\begin{array}{l}x \\
L \\
x \\
- \\
\text { V }\end{array}$ & $\begin{array}{l}\text { リ } \\
\text { シ }\end{array}$ & $t$ & $\begin{array}{c}\text { ダ } \\
\text { ル } \\
\text { タ } \\
\vdots \\
\text { ン } \\
\text { 陻 }\end{array}$ & 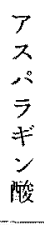 & 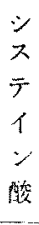 & $\begin{array}{l}7 \\
ル \\
キ 1 \\
= \\
ン\end{array}$ & $\begin{array}{l}\text { 匕 } \\
x \\
y \\
y \\
y\end{array}$ & $\begin{array}{l}y \\
\forall\end{array}$ & 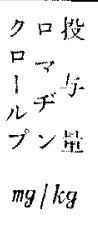 & 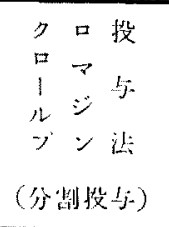 & 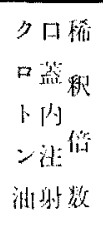 \\
\hline 54 & 28 & + & + & + & $T$ & + & + & + & + & + & + & + & 1 & 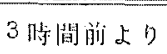 & 200 \\
\hline 55 & 33 & + & + & + & + & + & + & + & + & + & + & + & 1 & " & $"$ \\
\hline 58 & 28 & + & + & + & + & + & + & $t$ & \pm & + & + & + & 10 & $"$ & " \\
\hline 59 & 27 & + & + & + & + & + & + & $t$ & + & + & + & + & 30 & " & " \\
\hline 60 & 27 & + & + & + & + & + & + & + & + & + & + & + & 5 & & 500 \\
\hline 69 & 40 & + & + & + & + & + & + & - & \pm & \pm & \pm & \pm & 10 & & " \\
\hline$\% 2$ & 46 & + & + & + & + & + & + & + & + & + & + & + & 10 & " & " \\
\hline 73 & 44 & + & + & + & $t$ & + & + & + & + & + & + & + & 15 & " & " \\
\hline
\end{tabular}

第 2 表 $\mathrm{C}_{6}$ 前処䈯時外リンバ液遊離アミノ酸

\begin{tabular}{|c|c|c|c|c|c|c|c|c|c|c|c|c|c|c|c|}
\hline 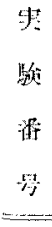 & $\begin{array}{c}\text { 外 } \\
11 \\
y \\
\therefore \\
\text { 禁 } \\
\text { ng }\end{array}$ & $\begin{array}{l}y \\
ル \\
y \\
\vdots \\
y\end{array}$ & $r$ & $\begin{array}{l}x \\
v \\
x \\
- \\
y\end{array}$ & ク & $-t$ & $\begin{array}{l}\not y \\
ル \\
\not \\
\Sigma \\
ン \\
\text { 酸 }\end{array}$ & 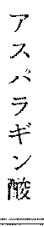 & $\begin{array}{l}* \\
x \\
\overline{7} \\
1 \\
\text { ン } \\
\text { 帷 }\end{array}$ & $\begin{array}{l}r \\
ル \\
\neq \\
= \\
ン\end{array}$ & $\begin{array}{l}\varepsilon \\
x \\
f \\
f \\
y\end{array}$ & y) & my $/ \mathrm{kg}$ & $\begin{array}{l}\mathrm{C}_{6} \\
\text { 掞 } \\
1 j \\
j j \\
\text { 法 }\end{array}$ & 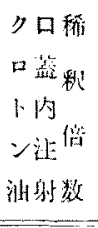 \\
\hline 74 & 30 & + & $t$ & + & + & + & + & - & - & - & - & - & 60 & 4 分彗掞与 & 500 \\
\hline 75 & 45 & + & + & - & + & + & + & + & - & \pm & 士 & \pm & 30 & 3 & " \\
\hline 76 & 59 & + & + & + & + & + & + & + & - & - & - & - & 60 & 4 & " \\
\hline 77 & 39 & + & + & + & + & + & + & + & - & \pm & \pm & \pm & 30 & 3 & " \\
\hline 78 & 38 & + & $t$ & + & + & $t$ & + & + & \pm & \pm & \pm & \pm & 60 & 4 & 200 \\
\hline 79 & 49 & + & + & \pm & + & + & \pm & - & - & \pm & \pm & 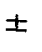 & 30 & " & " \\
\hline
\end{tabular}

阻止し得なかつた（第1 武).しかしながら Hexamhonium $\left(\mathrm{C}_{6}\right)$ の解投与样では， アルギニン。 とスチ ン、リジンといらヂアミ，酸の出現は，6例中 4 例に

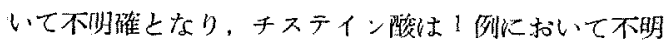
（土）であつた以外は，全て㓌性（一）で扬つた。

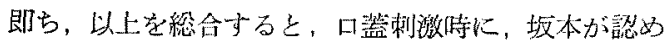

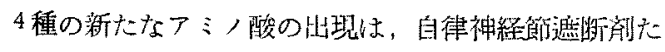
$\mathrm{C}_{6}$ により阻止できたので扔る。

第四節 総括韭び考接

自徫神経の均衙障碍並びに钻乱が，多くの矤舁の形 的要因として，大きな役制を演しているという考次

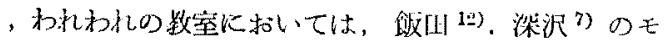

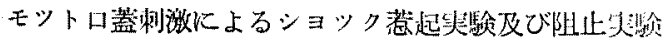
958）を始めとして，次第にこの形を整次つつあつた ‘鈴木が，仏国の J. Reilly 实駼室を部間して以後こ

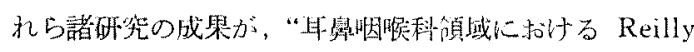
現象引”之題して，末とめた形で報告されるに至つた。 既に本邦において，山口 ${ }^{60)}$. 土屋 ${ }^{62}$ ) らの詳細な紹分火 より明らかな如く，1929年 J. Reilly 29) 30)《゙, チ>ス

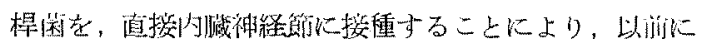

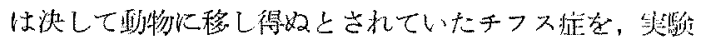
的に作りあげることに成功し，各租織，器官の間に，数

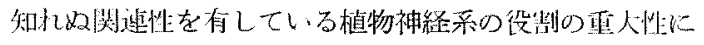

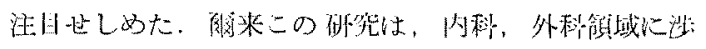

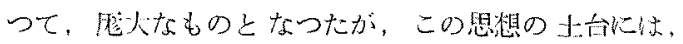

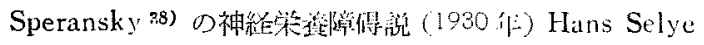

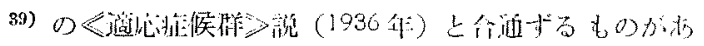

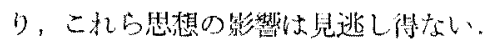

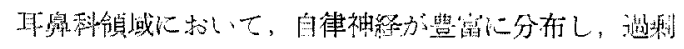

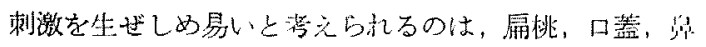




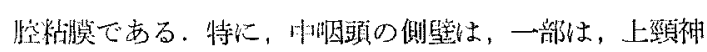

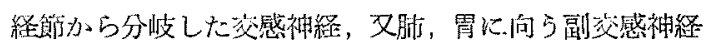

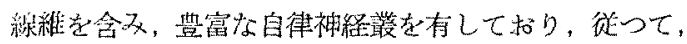

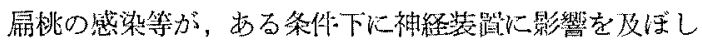

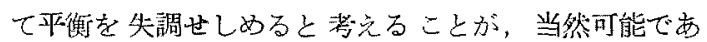
る.往つて，ヂフデーや猩紅熱の，胜アンギーナは

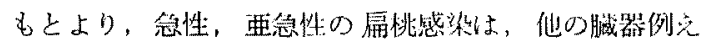

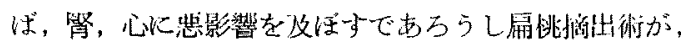

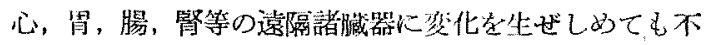

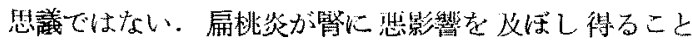
は，耳鼠科皆のあま权く知るとこるでもある。

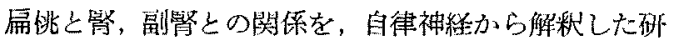
栄は, Brocard, Frumusan $p$ R. Coagne (1928) J. Reilly, A. Laporte, A. Compagnon \$1) (1942) Guido,

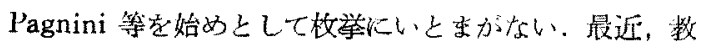

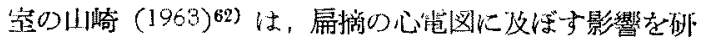

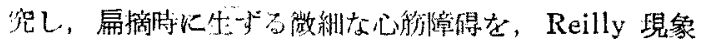

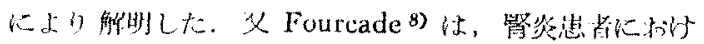

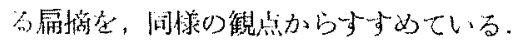

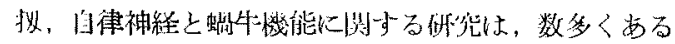

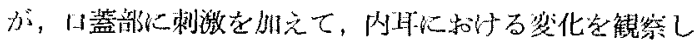
たのは，L.G. Chevance ${ }^{2)}$ が始めであり，次いで，伊

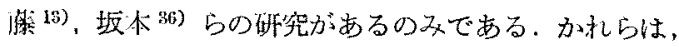

口馌刺激持に，外リンパ液中に出現する。リヂン（分子 量183.1) アルギニン（分子量 210.2）ヒスチヂン（分子 量155.2) システイン酸の形で見出されるチスチン(分 子量 200) が，正靠時に見出される 7 種のフミノ酸より む分子量が大であることから，これらの出現は， 口蓋過

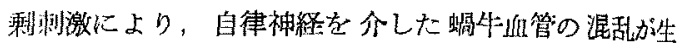

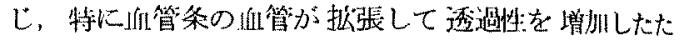

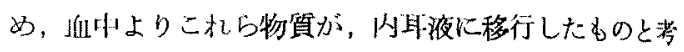

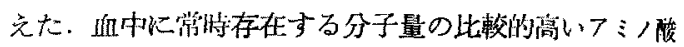
が，阻管条の透過性元進により外リンハ液中に出現する ならば，内耳血管の摭張を生ぜしめるよらな、なんらか の桨成を投与することによつて，同様な成縜が得られる のではないか，このよ5な洛圥のるとにわたくしは，

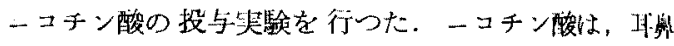

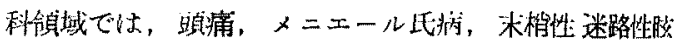

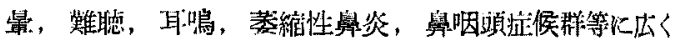

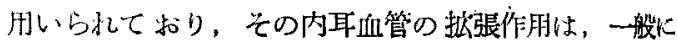

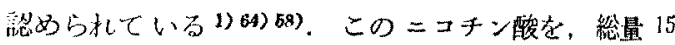

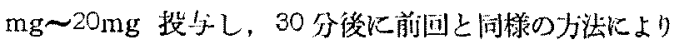

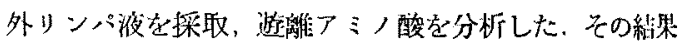
は第る表に示すごとく，明らかなシステイン酸の出現方

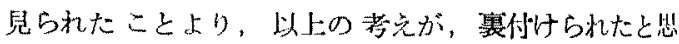
5.

第 3 表 一ユチン酸投与時外リンパ液遊䧽アミ，酸

\begin{tabular}{|c|c|c|c|c|c|c|c|c|c|c|c|c|c|c|}
\hline $\begin{array}{l}\text { 牙 } \\
\text { 歌 } \\
\text { 番 }\end{array}$ & $\begin{array}{c}\text { 外 } \\
y \\
y \\
\text { 品 } \\
\text { 量 } \\
\text { mg }\end{array}$ & $\begin{array}{l}\not ூ \\
ル \\
タ \\
\vdots \\
y\end{array}$ & $\begin{array}{l}\vec{\gamma} \\
\bar{Y} \\
= \\
ン\end{array}$ & $\begin{array}{l}x \\
\nu \\
\lambda \\
= \\
ン\end{array}$ & $\begin{array}{l}\text { リ } \\
\text { シ }\end{array}$ & $七$ & $\begin{array}{c}\not ゙ \\
\text { ル } \\
タ \\
\vdots \\
\text { ン } \\
\text { 酸 }\end{array}$ & \begin{tabular}{l}
7 \\
2 \\
\hdashline 0 \\
$\bar{y}$ \\
$\neq$ \\
$\dddot{y}$ \\
酸
\end{tabular} & $\begin{array}{l}\dot{y} \\
x \\
\bar{y} \\
1 \\
y \\
\text { 酸 }\end{array}$ & $\begin{array}{l}ア \\
ル \\
\neq \\
= \\
ン\end{array}$ & $\begin{array}{l}\text { E } \\
x \\
チ \\
チ \\
ン\end{array}$ & $\begin{array}{l}シ \\
\text { シ }\end{array}$ & $\begin{array}{l}\text { 二投 } \\
\exists \\
\text { 千与 } \\
\text { 年 } \\
\text { 酸量 } \\
\\
\mathrm{mg} / \mathrm{kg}\end{array}$ & $\begin{array}{l}\text { 分 } \\
\text { 割 } \\
\text { 法 }\end{array}$ \\
\hline 88 & 32 & + & + & + & + & + & + & + & + & \pm & + & + & 15 & 30 分前より 2 分割 \\
\hline 90 & 34 & $t$ & + & + & + & + & + & + & + & \pm & + & + & 15 & " \\
\hline 95 & 48 & + & + & + & + & + & + & + & + & + & \pm & + & 20 & $"$ \\
\hline 96 & 42 & + & + & + & \pm & + & + & + & + & + & + & + & 20 & " \\
\hline 97 & 43 & + & + & + & + & + & + & + & + & + & + & + & 20 & $1 "$ \\
\hline
\end{tabular}

1951 年 Laboriot ${ }^{17}$ 义び Hugnenard 5たよつて䀽 生した人工冬助狂证以来 Chlorpromazine は，各方面

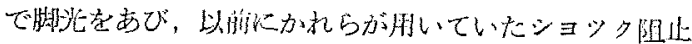

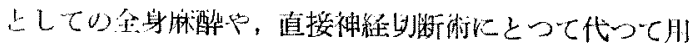

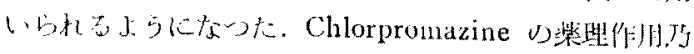

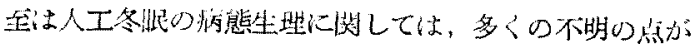
あるとしても，その奏效機序は，ショック初期の血管収

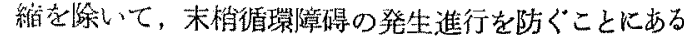
と考光られている，植草 (1955)49) らは，ショック例で

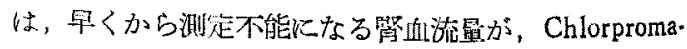
zine 投与により，かなり速加回復することを見て

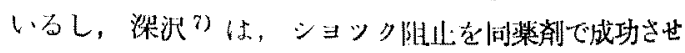

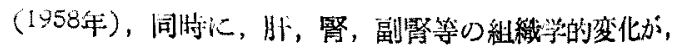
㧕制されるのる観察している。文，安田(1960年)，坂 
口(1961年) ${ }^{40)}$ ，杉山（1964年）41) 等は，各々腸間膜細 小血管，血流，及び脳波の異常を Chlorpromazine で

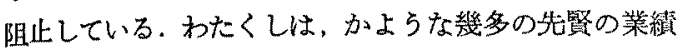
に爁みて，口蓋過剩刺激が Chlorpromazine にて抑制 できる予想したが，この期待は害切られ，意外の感を 抱か寸には括られない. しかし，わたくしが，次に䏘い た $\mathrm{C}_{6}$ は， methonium 化合物の5ちで取も作到が強力

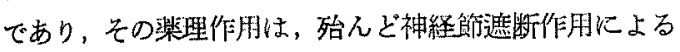
すのであるとされている.この楽㥔の循環系に対する二 次的作用は，血生を下降し，末悄血流量を增大するた

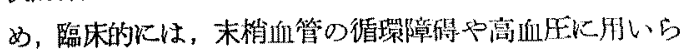
れており，内耳近流えの影暗当当然考慮されればならぬ が、これに関す研究は見当らない，いずれにしてb

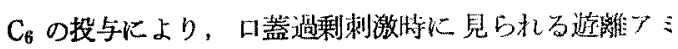
ノ酸の出現が抑制されることは，㴬たなてミ，酸の山現 に，口蓋刺激による自律神経系の関与が洘えられる証明 である. Chlorpromazine による，新たなアミ，㖹出現

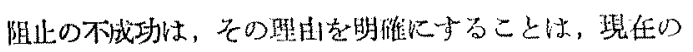

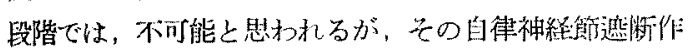

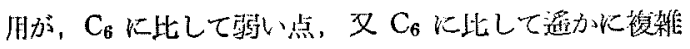
な作用を有与るために，他の因子の効果が現わ机たため

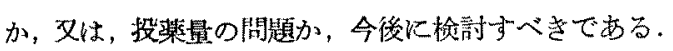
しかし，わたくしは，上り純粋な神経節遮断作用を有す

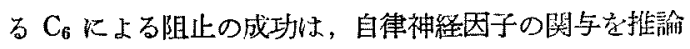
する上に，更に偍利な結果であると考えている。

\section{第 III章 外リンバ液, C.R.P. 出現阻止に 関する研究}

1930 年, 米国の 2 学者 Tillet と Francis ${ }^{44)}$ によつ て，急性肺炎患者の血清中に，最初に発見されたC.R.P.

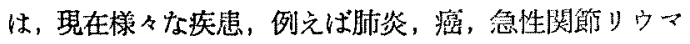
チ，心胳梗塞，心内嗼炎、等の経過中に現われることが

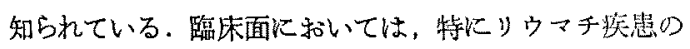
消長の指標としての洒值が想められているが未だにその 本体は明らかではない，この巽常蛋白部分が，口㦈刺湤 時に，外ッンパ中に出現することを，鼠初に見出したの

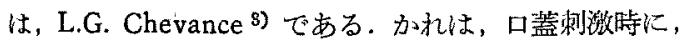
新たなアミノ酸が，外りンパ夜中に出現することにヒン トを得て，体蛋白の崩㙳が原因で生ずると考えられてい た C.R.P.が，多くの細胞㑺憲が証明されている Reilly

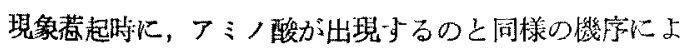
り, 外リンパ中に現われるのではないかと考之, これを 実婨的に証明した。この興味ある实験は，以来，本邦に

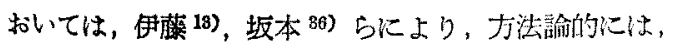

各々，多少とも異つた形ではあつたが追試されたおた くしは, C.R.P. の出現が，加らの云ら如く，自律神 経を介するむのであるならば，自律神経の不均衡が生ず

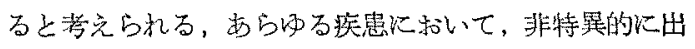

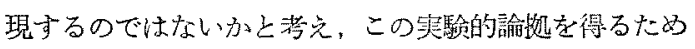

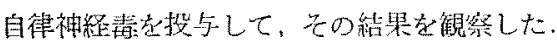

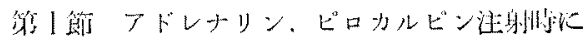

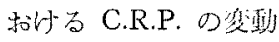

籍 1 項 检楂材“料及び投与方法

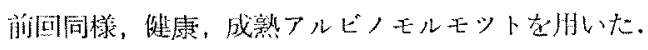

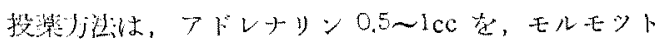

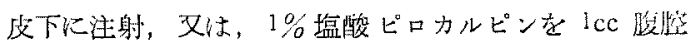
内，皮下又心口盖闪注射し，1时間後に，正円笲より毛

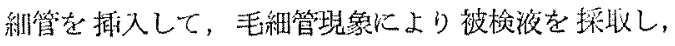
Hyland 补製 C.R.Test を䏘いて湘定した，外リンパ 液採取可能琵は，1 耳につき，0.01cc 程度でするが，わ

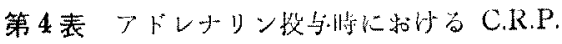

\begin{tabular}{|c|c|c|c|c|c|c|c|}
\hline 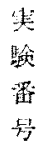 & $\begin{array}{c}\text { 外 } \\
1 \\
2 \\
\text { 淮 }\end{array}$ & 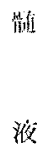 & ifll. & 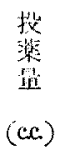 & $\begin{array}{l}\text { 拉 } \\
\text {-j- } \\
\text { jj } \\
\text { 法 }\end{array}$ & 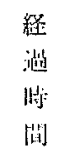 & 将 \\
\hline 99 & - & - & - & 0.5 & 皮下注 & 30 分 & エーテル \\
\hline 101 & - & - & - & 0.5 & " & " & $"$ \\
\hline 102 & - & + & - & 1.0 & " & " & $"$ \\
\hline 108 & - & - & - & 1.0 & " & " & $"$ \\
\hline 106 & - & - & - & 1.0 & " & $"$ & " \\
\hline 108 & - & - & - & 1.0 & " & " & " \\
\hline
\end{tabular}

第5表 ピロカルピン投与時に斿ける C.R.P.

\begin{tabular}{|c|c|c|c|c|c|c|c|}
\hline 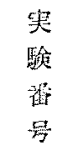 & $\begin{array}{c}\text { 外 } \\
y \\
y \\
\therefore: \\
\text { 液 }\end{array}$ & 筫位 & 血 & $\begin{array}{l}\text { 投 } \\
\text { 翡 } \\
\text { 朢 } \\
\text { (cc) }\end{array}$ & $\begin{array}{l}\text { 投 } \\
\text { 与 } \\
\text { j } \\
\text { 法 }\end{array}$ & $\begin{array}{l}\text { 経 } \\
\text { 䢛 } \\
\text { 時 } \\
\text { 閶 }\end{array}$ & 麻 \\
\hline 109 & - & + & - & 1.0 & 皮下注 & 30 分 & エーテル \\
\hline 110 & - & - & + & " & " & $"$ & $"$ \\
\hline 111 & + & - & + & " & $"$ & 60 & $"$ \\
\hline 114 & - & - & - & $"$ & $"$ & 120 & " \\
\hline 115 & + & - & + & 1.0 & 腹腔内 & 30 & " \\
\hline 119 & \pm & - & + & " & " & 30 & " \\
\hline 120 & - & - & - & " & $"$ & " & " \\
\hline 121 & - & - & - & 0.4 & 口蓋内 & 60 & " \\
\hline 123 & \pm & - & + & $"$ & $"$ & " & " \\
\hline 124 & - & - & - & " & " & $"$ & 4 \\
\hline
\end{tabular}




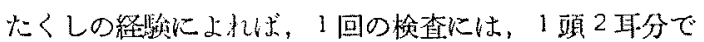
充分であった，注射後動物は，多少の不安状態を是した のみで，激しいショック症状は起さず，1时間後に死亡 したものは無からた。

\section{第 2 項 检查成維}

アドレナリン投与によりて，1 例に，䯣腹吽の C.R.P. 陽性を得た。他住全て㓌性であつた。

ピロカルピン投与によつて蚛，外りンパ液叹の C.R.P. の出琴は，10例中 2 例で $20 \%$ ，疑防性を合わせると 40 \%であり、血清党の出現は 50\%であつた。䯣液中へる1 例の出現が，钼祭された。

\section{第 3 項 総括並びに考撄}

わたくしは，交感神程節後線維に作用する楽物の代表 として，アドレナリンを，又副交感神経節後線稚を刺激 する代表楽にピロカルピンを撰択した。 その結果，アド レナリンによるよりる，ピロカルピンに拀いて，C.R.P.

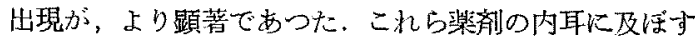

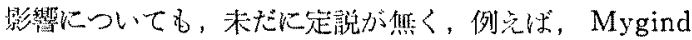
19)(1958) らは，大量のアドレナリン投与は，モルモッ

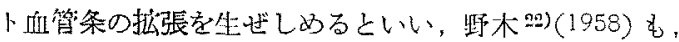

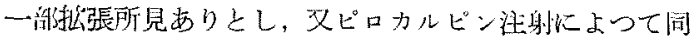

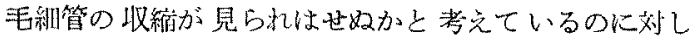
Wittmaack ${ }^{52)}$ (1928), 立不 ${ }^{45)}$ (1952), 吉田 (1952) 5 は，ピロカルピンによる内耳蛸年血管条の扰大を，又ア トロピン，アドレナリン，による維少を見ている、双渡

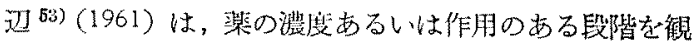
察することによつて，取縮も抬張も，みられるのではな

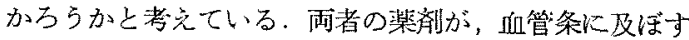
影響の及去取上げても，かように意見の相違が女る。し かし，外リンパ夜中の C.R.P.の出現は，他の多くの因 子が加かるにせ上，ピロカルピン投与時に，血管条が搪 大するといら顶により，近中の C.R.P. が透過して，外 リンバ液中に琴かれたと解釈少ると都合がよい，C.R.P.

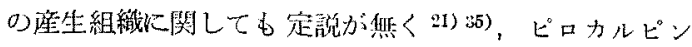

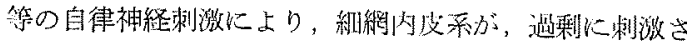

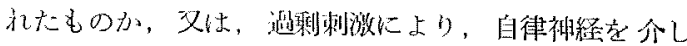
て, 他の臟器に被化が止し，ここに発生した C.R.P.

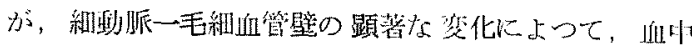
に，臂源に，双は，外リンバ液に末でも执散したもの

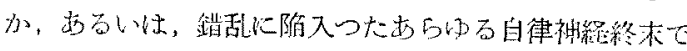
生したものか，正確な解答は困難である。いずれにして

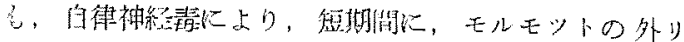

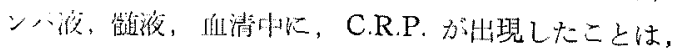

この機序には，行来から云われてきた炎柱性因子のみで はなく，自律神経系因子の哭与が存在することの証抸で 古ると思加れる。

次の閣題は，アミノ酸及び C.R.P. が，主に螖牛血管 条から侵入するとするならば，队リンパ䐦にですつて， 外リンパ腔ではないのではなかららかといらことでお る、確に，両内耳液は， $\mathrm{Na}, \mathrm{K}$ 等の電解質を始めとし て組成に差異があり，雨耳液間の交通性沉は，なんらか の制限が存することは明らかではあるが，量こそ異な れ，内，外リンパ液に，同様の遊離了ミ，酸（松生）,

C.R.P. (的藤) が見出されることは，内，外リン八液 は，互に流通していると考えて最いと思ら、数空の荻原 10)は，前庭膜の䉓子顕微鏡学的呼究で，この膜が，以， 外リンパ液の物質の撰択的交流を許しているといら重要 な所見を得ている(1963)。

又血管条は，決して孤立血管ではない故，その前後の 外リンバ腔に面する血管，例之ば下らせ儿勒带や，鼓室

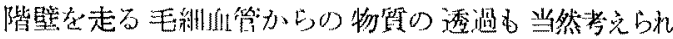
る。

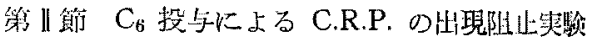

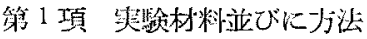

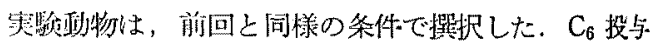
量6，遊猚アミ八酸阻止笑喝と同じく，総量 $60 \mathrm{mg} / \mathrm{kg}$ の3分割投与淁を朋いた。

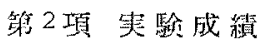

モんモットは，第 3 回日の注射走受ける頃は，著明な

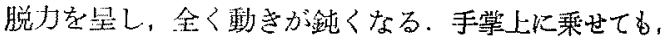
ぐつたりとして，激しい抵抗を見せず，明らかに低血正 を生したことが推测される。稀釈クロトン油による口蓋

第 6 表 $C_{6}$ 前置処による C.R.P.の 出現阻止效果

\begin{tabular}{|c|c|c|c|c|c|c|}
\hline $\begin{array}{l}\text { 歨 } \\
\text { 檗 } \\
\text { 萿 } \\
\text { 号 }\end{array}$ & $\begin{array}{c}\text { 外 } \\
\text { y } \\
y \\
\text { 液 }\end{array}$ & 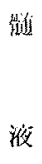 & 近 & $\begin{array}{c}\mathrm{C}_{6} \\
m g / k g\end{array}$ & $\begin{array}{l}\mathrm{C}_{6} \\
\text { 投 } \\
5 . \\
\text { 法 }\end{array}$ & $\begin{array}{ll}\text { ク } & \text { 稀 } \\
\text { 口 } & \text { 积 } \\
\text { 卜 } & \text { 倍 } \\
\text { 站 } & \text { 数 }\end{array}$ \\
\hline 150 & - & - & - & 60 & 4 分㗼投与 & 200 \\
\hline 152 & - & - & - & 60 & " & " \\
\hline 160 & - & - & - & 60 & " & 500 \\
\hline $1 \leq 3$ & - & \pm & - & 30 & 3 & 200 \\
\hline 151 & - & - & - & 30 & " & $"$ \\
\hline 163 & - & & - & 30 & $"$ & 500 \\
\hline 166 & - & - & - & 30 & " & " \\
\hline
\end{tabular}




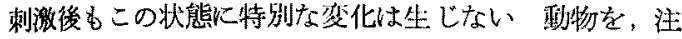

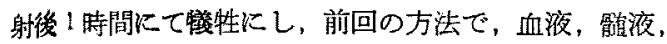

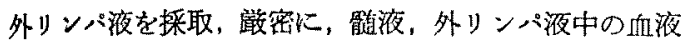
污染を避け，CR-Test にて，反応を観察した。その結 果は第6表の如く，外リンパ，血清，骮液中の C.R.P. の出現は阻止さ礼た。

\section{第3項 総括並びに考按}

以上，わたくしは，C.R.P，の出現抑成に成功した。

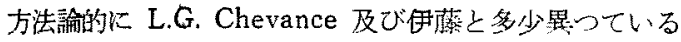

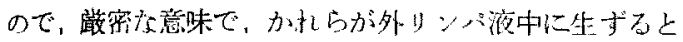

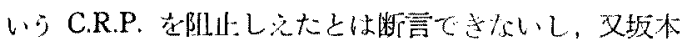
も，わたくしと同一の口蓋测激方法及び分析方法を用い $\tau$, Chevance の報告の如く $100 \%$ に近い C.R.P. の出 現を発表しているかけてはない故，この阻此の洒杰，遊 離厂ミノ酸阻止に匹適与る程高いとは云えない，しか L， $C_{6}$ により，C.R.P. の出現が，血清，䯣液，外りン 液共比排されたことは，この機序に，自律神経系の 閔与を想定しらるるのと考える。

さて次に，品篮刺激を加えた場会，刺激が経由する神 経路であるが，これに付いては，幾多の不明確さはある にせよ，大部分が，頸部交感神経を通り，上頸神経節上

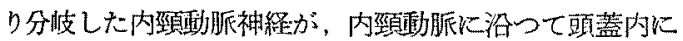
入り，大脳動脈輪飞て，左右互に吻合し，更に脳底動脈 では，星状神経節より椎骨動脈と共に上行した交感神経 線䊒と吻合して，脳底動脈上り分岐する 迷路呩脈を経

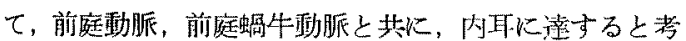
えられている，又小部分は，内頸動脈から鼓室神経叢を 介して，内耳に入るとされている. 又小部分は，内頸動

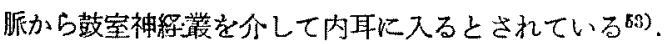

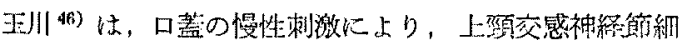

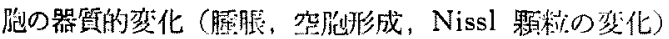

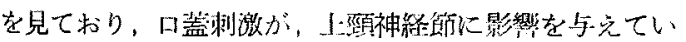

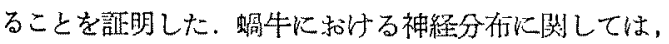
Ergmei (1936), 指南 (1938), Racine (1942), Agazzi 66) (1945), Smith ${ }^{33)}$ (1951), 渡辺 ${ }^{53)}$ (1961) 等の研究

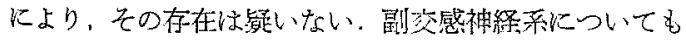
Rasmusen (1945), Fernadez (1951), Rambo (1953), 岩时 (1960) 等により，内耳に分乕する経路怔迫究され た. 最近，杉山 ${ }^{41)}$ (1963)は，口盖過剩刺激時に，象の朕 波に変化が認められることにより，兴に至る自律神路求 心路を想定し，口蓋過剩刺激は，一且脳中枢に達し，て れから末梢植物神経を絽て下降し，遠隔蔵器に，血管系 を主体とした变化を生ずるのではなかららかと考えた。
このょうな，自律神経分布及び，各種の咸器裂化から 考えれば，アミノ酸や C.R.P. の如き，内耳液の生化学

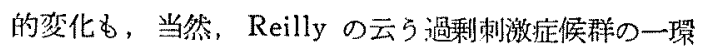
として，捕えられても不焽議ではなからら。

\section{第IV 章 アナフィラキシーショツク薏起時に おける, 外リンパ液, 埴液, 血清の C.R.P.}

口蓋過剩刺激症犊群に見られる㴊烈なショック症状に 類したものに，アナフイラキシーショック，又上ス夕ミ ンショツク等があげられる，J. Reilly 注既に，1936年

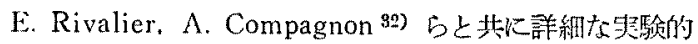

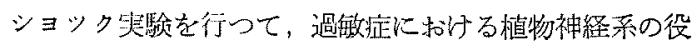
割を明らかにした，加たくしは，馬血清により，モルモ ットにアナフイラキシーショック．及び，七スタミンに

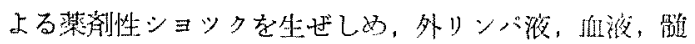
液中の C.R.P. を而嵒した。

第 I 節 检植材料恶びに方法

300〜350gr. 婎性，健康なアルビノ禾モルモツトを使 用した。

通常行なわれるショック薏起試験汇留い，0.25cc の馬 血清を，モルモットの腹腔内に注射し，抗体産生期間と いわれる3週間後に，馬血清約 $1 \mathrm{cc}$ を，㲔発注射とし て股静脈より注射する、動物は通涪5〜10 分にて，湤烈 なショック症状を呈して死亡する。死亡寸方解に，顝液， III液，外リンバ液を採取，C.R.P，を測定した。

第』節 検查成績

実駩は，8例について行ない，榴液中には2 例に，血 清には 4 例に陽性の結果を得た，外リンパ夜中の出現

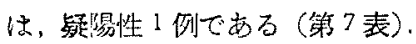

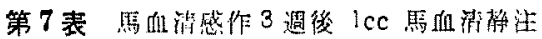
(C.R.P.)

\begin{tabular}{|c|c|c|c|c|c|}
\hline $\begin{array}{l}\text { 実 } \\
\text { 験 } \\
\text { 獣 } \\
\text { 号 }\end{array}$ & $\begin{array}{l}\text { 保 } \\
y \\
\text { ソ } \\
\therefore 0 \\
\text { 液 }\end{array}$ & 䨝 & IIIL & & \\
\hline 130 & - & - & + & 5分後ショ & シク死 \\
\hline 131 & - & + & 一 & 腈閏後 & " \\
\hline 132 & - & + & + & 5分段 & $"$ \\
\hline 134 & - & - & - & 6分俊 & 1 \\
\hline 135 & - & - & + & 10 分传 & " \\
\hline 136 & \pm & - & + & 8 分娞 & " \\
\hline 138 & - & & - & 19召媱 & " \\
\hline 139 & - & - & - & 21 分络 & $"$ \\
\hline
\end{tabular}


第可穊 総括並びに考按

アナフイラキシーショックを，正確な串験の基礎にも とずいて報告した最初の人は，Behring (1893年) の思 考を受けつけ Charles Richet (1902) であり，午の 後 Gay et southard らは，モルモットに，イソギンチ ヤク毒素を再接種して、アナフイラキシーショックを生

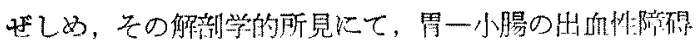
を明らかにし，更に Anderson た Rosenau bす，血 清の再接種に際し，伹管系を主体とする病变が生ずるの

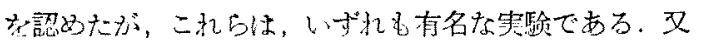

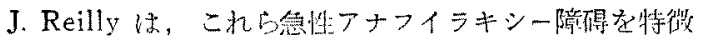

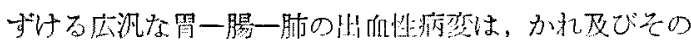
一派が，植物䗝経を赖激したり，畦碍したりして得た病 理解剖学的所見と同一の型の病恋であるとこるから，ア ナフイラキシースはフレルギーを特微ずける生体反応の 全体は，植物神経系の摄乱にもとずくあのではあるまい かと考兑た。 か子は A. Lumière や Mme. Enselme の血管内膜の神経終末を麻咞することに上り，フナフイ

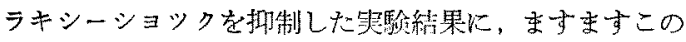

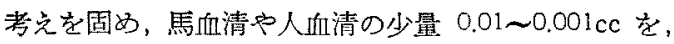

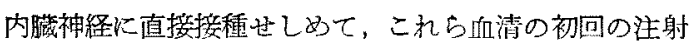
に执いて串，1〜2日後に，胃の出血性病恋を生じて， 動物が死亡することを観察し，従つて，皮下あるいは血 管中に行なわれた所謂る準唃注射が，緩徐に，目立たず に，植物神絽系に唀し，同㭙に，抗体の商生を坐ぜし めるであるらと考えた。

現在、アナフイラキシーの成立機序に関しては，液体

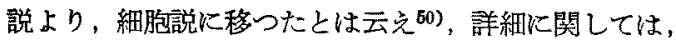
専門家の間でる意見の一致を見ていないよらである．植 物神経のみで，この多元的な現象を㨔えることは然理が

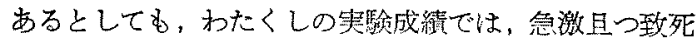
的なアナフイラキシーショック㭙に，L.G. Chevance,

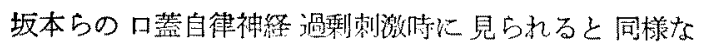

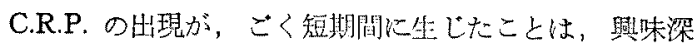
い知塄である。

な机，誘発注射前のモルモツトは，5例に执いて，

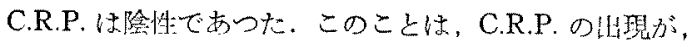
誘発洁的から，政物が死に到つたごく短期間に起つたこ

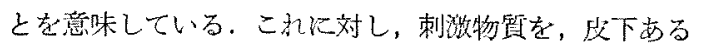

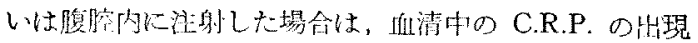

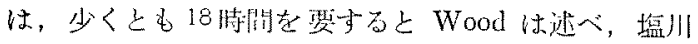
35)，辻らは家要にチフスワクチンを注射し，時䦓を道 つて採血，C.R.P.を检したところ，6時間後に始めて
出現を見，大部分の出現は，24时間後であつたと報告 (1959) している.

第W筑 とスタミン投与時の C.R.P.

フナフイラキシーショツクと同様, 激烈なショック症 状を生ずるものとして、ヒスタミンショツクを忘れるこ とはできない・フナフイラキシーショックの成立機序 に，ヒスタミン説があり，この説の占める籍因は大なる ものがある，わたくしは，健康，成熟モルモットK，上 スタミン $0.5 \mathrm{mg}$ を皮下あるいは口蓋に注射して，その

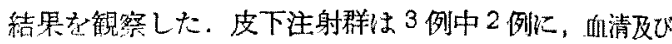

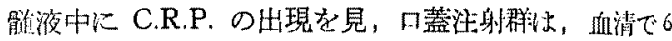

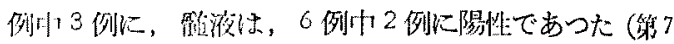
裴).

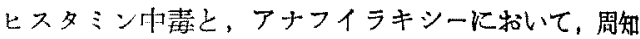
の如く，その症状が酷似し，アンチゲンと細胞障碍が， ヒスタミンの生成を招来するるのと考党られている．高 木 ${ }^{47}$ らは，アナフイラキシーに際して，モルモットの 血山にヒスタミンの增加が見られ，それは，フナフイラ キシ一発現の初期以最も泟しく，最初の 10 分閒に, 正 常诗の8倍量にも達すると述べている。

わたくしの牙験に括いても，馬血清アナフィラキシ 一、㕛はヒスタミンショックを生ぜしめた時の C.R.P. の出現状態が類似していることは，この雨者間に共通点 があることを物語つている，又興味深いのは，この両资 料では，外リンパ液中の C.R.P. 出現が殆儿ど見られな かつたことで，ピロカルピン投与特とは多少舅つている にせよ，坂本が，口蓋過剰刺激で得た数值と，ほ注同様 であることである、更に，ヒスタミン，ピロカルピン投

第 8 表 ヒスタミン投与時の C.R.P.

\begin{tabular}{|c|c|c|c|c|c|c|c|}
\hline 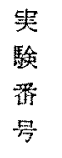 & $\begin{array}{c}\text { 外 } \\
y \\
y \\
\therefore \\
\text { 液 }\end{array}$ & 䠝 & 清 & $\begin{array}{l}\text { 挑 } \\
\text { 薬 } \\
\text { 战 } \\
\text { (cc.) }\end{array}$ & $\begin{array}{l}\text { 投 } \\
\text { 与 } \\
\text { 方 } \\
\text { 法 }\end{array}$ & $\begin{array}{l}\text { 経 } \\
\text { 邀 } \\
\text { 時 } \\
\text { 間 }\end{array}$ & 酷 \\
\hline 130 & - & + & $H:$ & 0.5 & 皮 下 & 60 分 & エーテル \\
\hline 131 & - & - & - & 0.5 & " & " & \\
\hline 140 & - & \pm & + & 0.5 & $"$ & " & \\
\hline 160 & - & + & + & 0.4 & 口䈉 & $"$ & \\
\hline 161 & - & - & - & 0.4 & " & " & " \\
\hline 162 & - & - & - & 0.4 & " & " & \\
\hline 163 & \pm & - & + & 0.4 & " & " & \\
\hline 164 & - & - & - & 0.2 & " & $"$ " & \\
\hline 165 & - & + & \pm & 0.4 & " & " & \\
\hline
\end{tabular}




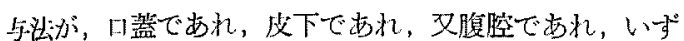
れにも，C.R.P. の出現加見られ， 目蓋の場所的特異性 が特に現われなからたことは，自律神絽系に㩏択的な作

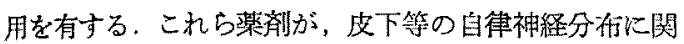
しては不利な点を覆い隠してしまつたが感がある。

フナフイラキシーと瞵り合和せの関係にあるものにフ レルギーがある，J. Reilly一派は，動物の内葴神絽に， ッベルクリン稀釈液を接着させ，次いで，琴壁内に、ッ ベルクリン注射を行ない，局所に血管系を主件とした病 变艺つくることに成功し，アレルギ一反成にも，植物神 経が役割を演じていることを愎明した。

わたくしは，現在，教室のアレルギー外来を訪れてい る鼻内所㒻，症状が，典型的と思われる鼻アレルギ一患 者を撰び，血清の C.R.P，を検查した。患者は８例（第 9 表)で, 就れも脱感作療法に用いる最も広筝, 且つ鋭 敏な抗原である鳥居製薬の house dust 皮内テスト陽性 曐でつた9)。方法は，一般に行なわれているDifco laboratories $の$ Bacto C-Protein Antiserum 試紮を用 い, 湘定法は Anderson, McCarty ${ }^{54)}$ 及び Swift $の$ capillary precipitation method によつた。結果は，8 例共 C.R.P. が陰性であつた. わたくしが，人体の家塵

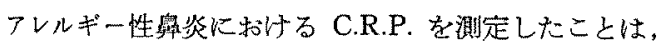

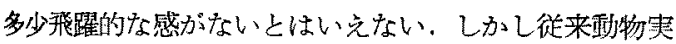
験に関しては，後藤 (1955)，三宅 20) (1953)，中島 24) (1954)，吉川 (1955)，伊藤 14)(1961）らの報告があり， 家兔あるいはモルモツトに，BCG 又は卵白溶液の使用 により，全身的及は中耳，内耳の局所的アレルギーを生 せしめ，この際，内，外リンパ液に和けるカタラーゼ

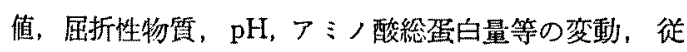

第9表 ハウスダスト皮内反応陽性者 C.R.P.

\begin{tabular}{|c|c|c|c|c|c|c|c|c|}
\hline 号 & 氏 名 & 性 & 令 & $\begin{array}{l}\text { 塺反 } \\
\text { 友応 }\end{array}$ & $\begin{array}{l}\mathrm{C} \\
\mathrm{R} \\
\mathrm{P}\end{array}$ & $\mid \begin{array}{l}A \\
S \\
L \\
O \\
O\end{array}$ & $\begin{array}{l}\mathrm{L} \\
\mathrm{F} \\
\mathrm{T}\end{array}$ & \begin{tabular}{|l}
$E$ \\
$O$ \\
$S$ \\
$I \%$ \\
$N O$ \\
$O$
\end{tabular} \\
\hline 14 & 浦○○差 & $\delta$ & 24 & + & 險性 & 333 & 㓌 & \\
\hline 63 & 鬲OO作 & 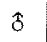 & 33 & $H$ & $"$ & 50 & " & 4 \\
\hline 62 & 塩 $\bigcirc \bigcirc 子$ & 우 & 27 & $H$ & " & 833 & $"$ & 8 \\
\hline 10 & 中 00 夫 & $\hat{\delta}$ & 31 & $\mathrm{Ht}$ & " & 50 & " & 1 \\
\hline 49 & 広 ○○庭 & $\delta$ & 33 & $H$ & " & 100 & 疑陽 & 4 \\
\hline 65 & 就 00 太 & $\delta$ & 8 & $H$ & $"$ & & & \\
\hline 33 & 具00子 & 8 & 23 & + & " & 12 & 陸 & 7 \\
\hline 18 & 維 100 政 & 3 & & + & " & 50 & " & 6 \\
\hline
\end{tabular}

つて、アレルギー状態に扣いて，炏液に止化学的变化

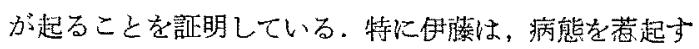

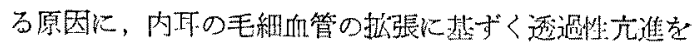
主体と考它ている. 娅物笑駼を, 直号に人休生理との比 較に和いて述べ得ないとしても，これら俥物に見られた 変化は，程度は弱くとも，人休に観察されても不思議で

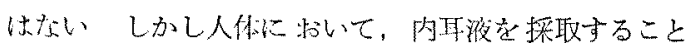
は，不可能である故に，わたくしは乎始めに，人血清を

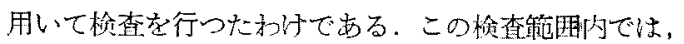
アレルギーを C.R.P.の関係は見出されなからた。この 点に用しては，一層の检尌が必要であるらが、フレルギ 一は、アナフイラキシーショックに比し強度から云え ば，遥か河く，局所的なものであり，C.R.P.に限つ て考えれば，人体に执いて，鼠アレルギ一症は，自律神 経の邉制刺激とはなり得なからたのではなかららか， C.R.P. の出現は，アナフイラキシーショックやヒスタ

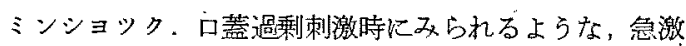
で激しい，㼭々致死的であるような㭙にのみ，自律神経 鍇舌の指標として急速に出現するものと思われる。

更に，C.R.P.は，動物種に上り異り，動物体に执い て，C.R.P.に相当与るものは，Cx.R.P.であるといわれ ている、Cx-多糖類は，本質的には，C一多崝類と同一

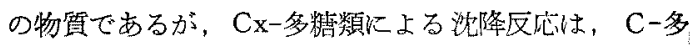
糖類による同反応よりも，より鋭敏であるとされ，CxRP は人類の他に，家宽その他の助清に見出されてい る.

わたくしは, Hyland 社製の試藤 CR-Test が, CxRP の試薬に充当しらるものか，䛨細を検討していない が，今泛の金駼において，モルモツトの而清，外リンパ

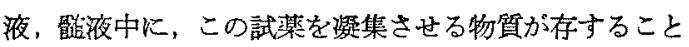
は, 既に L.G. Chevance, 伊藤, 坂本らの研究によつ ても明確な故に，この試薬を用いた。

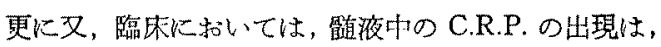
かなりの病要老有する場合も险性に止つて拈り，一般に は出現しないと考えられている C.R.P.が，わたくしの

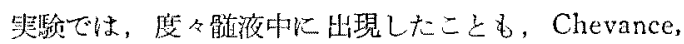

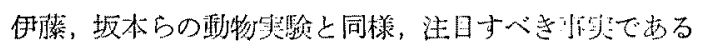
と思う。

\section{第 $\mathrm{V}$ 章 蛤牛血流の動態より見たる上記 変動に対する考察}

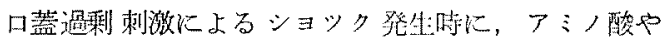
C.R.P.が，内耳液へ出現することは，自律神趶系を介

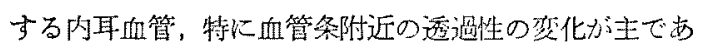


ろらと考えたわたくしは，内耳血管の生体観察を試み た.この研究の経過中, 教室の坂本, 神崎と共に, 血管 条血管のカラーフイルムによる撮影を行つた。

第 I 節 検查材料並びに方法

以上の実験にならい，300〜350gr の成熟，健康，ア ルビノモルモットを使用，25\%ウレタン麻酔下に気管 切開を施し，下顎内側に切開を加它て骨胞に達し，これ

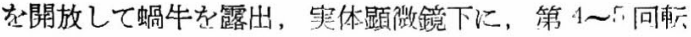
部に小刀を用いて，直径約 $1 \mathrm{~mm}$ の孔立あけ，ライッ 社製の，ウルトッパークミクロスコープを用いて，32 管から 220 倍の倍率で，観察，並びに撮影を行つた（1 図，2図). 従来の研究は，充分な光量を確保すること に難色が示されていたが，われわれはキセノンランプと 断熱フイルターを用いて, 顕微鏡側面より，集光レンズ で光を入れることにより，この点を補つた。

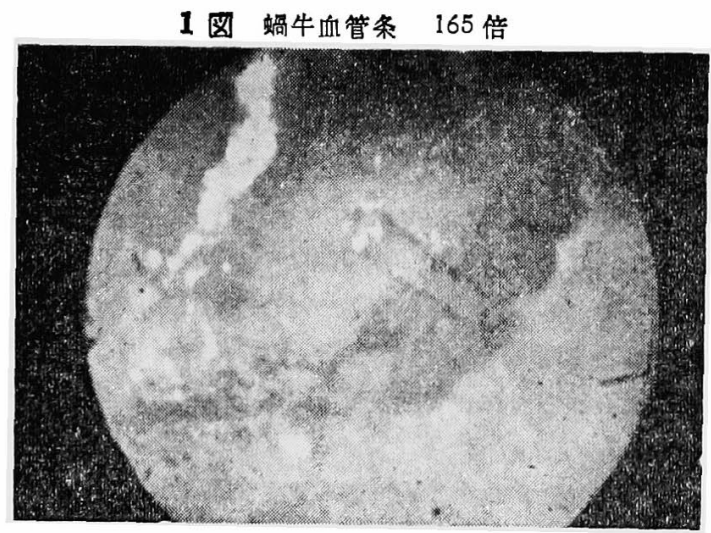

2 図 螎牛和管条 220 倍

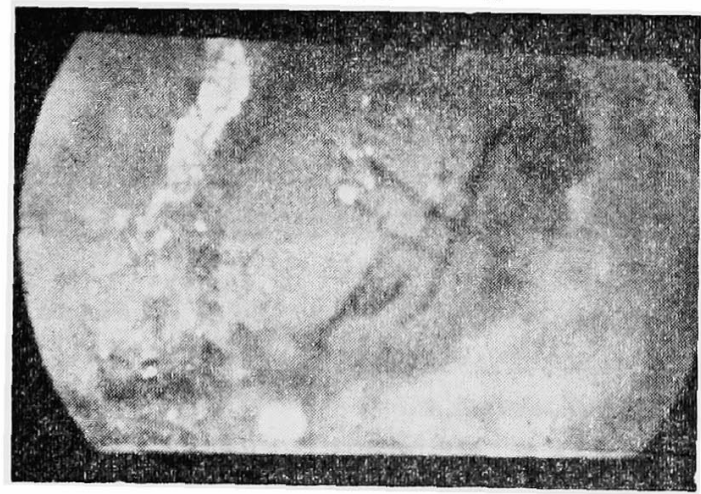

第》節 檢查成績

投楽前に微察される血流は，極めて安定しており，血 管の自発性，収縮，扗張は起らない，無拍動性に，赤血
球の群が，極めて滑らか，且つ式速に移動し，白血球の 移動も時折観察される. 細い放射状小動脈の急速な流れ は，血管条の網目中では，やや低速となる，わたくし は, 温度, 音響, その他の不必要な刺激を, できるだけ 避け，環境を一定にして，前実験に使用した薬郕 (1) コチン酸 $10 \mathrm{mg}$ 皮下注射, (2) $1 \%$ 塭酸ピロカルピン। cc 筋注, 及び腹腔内注射, (3) 塭酸エピレナミン lcc 皮下注，(4)クロトン油 $0.4 \mathrm{cc}$ 腹部皮下注射の群につき，

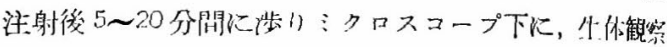

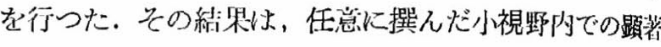
な変化は，生し゚なからた。(5) ヒスタミン0.4cc 皮下注 射も，特別な変化は観察されなかつた。（6) 馬向清の馀 発注射に拉いては，ショツク死寸前と思われる洔に，血 流速度の著明な減少, 勘静脈弓部に㧍ける反復性一眝血 行停止，栓塞，又一部血管の拡張之も考えられる所見を 得た例があつた。

\section{第四節 考 按}

内耳血管系に與味が 持たれるに至つたのは，19 世紀 中頃からであり，1887 年 Swalbe により，一応螖牛全 体の循環系図ができ上つた。1892年 Eichler は，染色 物質を㧈管中に注入して，耳のセロイジン包理を行な い, 1894 年 Siebemmann ${ }^{65)}$ は，人体循環の研究中， 膜㥆迷路の血液供給が，骨性被膜部分と完全に異つてい ることを強調した。

血管条の毛細管図は，1951 年 Smith, C.A. ${ }^{38)}$ の詳絸 な報告が見られ，映画撮影に関しては，1955 年 H.B、 Perlmann, R.S. Kimura 27) 28) らの研究があり，最近 本邦に特いては，切替（1961）ら，菅野 43) (1963) 50 研究が散見されるが，末た゚に，カラーフイルムによる撮 影は成功していない，又浂来，血管条血管や，放射状紐 動脈の近管は，様々な刺激に対して，極めて安定した動 き走示し，血流速度は变化しても，血管系の变化は生じ ないと言われてきた。 Perlmann, Kimura らは，螖牛 開空部の音響振動, 涇部交感神経幹の切断, 更に電気刺 激による 星状神経節，上頸神経節等の刺激は，中耳血 管と異つて，可視的な血管及び血流の恋化を生ぜず， asphyxia の状態に枕いては，血流の增加はあるが，血 管の太さの变化はないと蕞告している。

最近，菅野 43) は, arterio-venous arcade あるいは, radiating arteriole における血管の明確な縮小を見た と報告し，以前の䂰究者らが，この所見を得ぬのは，直 径が $100 \mu$ 以上の小孔を穿つためであると述べている. わたくしの実験範用内において，自律神経剂投与時， 
又は，ヒスタミン，クロトン油等の皮下注射により，著 明な可視的变化は得られなからたにせよ，まだ，まだ， 菂威投与量とか拔術の面で，梌討の余地が多く残されて いる. ラッテロ蓋刺激時の腸間膜血管の動態に関して は，坂口 ${ }^{40)}$ の研究 (1961) があり，刺激時には，血管 の収縮に次く㹡張が観察されている，しかし，腸閏膜の 血管で血流を諭ずるならばともかく，血管条でも生じて いると考学られるこれら，执張，収篗の現象を顕敝鏡下 に㨔えることは，1 コの赤血球をかららじて通過せしめ るような細い血管を対象に、又ごく狭小な視野で，多少 とも広範な装化を観察せねねばなら故に容易ではない

又, 実際に，一部の血管に栓塞が生じても，副行循塄に 实いては，代償性に，上り血流速度が增大していること む十分考克られ，この場合，主流と傍流の血行を同时:

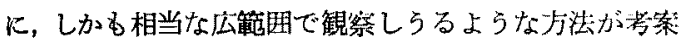
されぬ限り，総体的な結論を下すことは危険である。而 湤速度に関しては，此較的容易に变化を追えるとして も，血管収縮に関して，血管条で婨ずることは，非常に むずかしい.

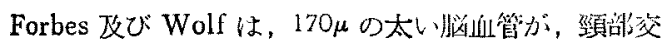
感神経の刺激によつて，僅かに $8 \%$ 程しか収称しないこ

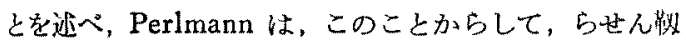
带心小血管化目に見总る变化を期待するのは無国である

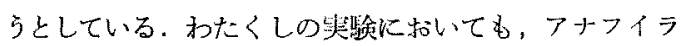
キシーショック诗に，一部血管が搪張している如き所見

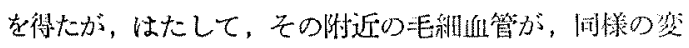
化を生しているかは疑閅である。この点に間しては，色 菜注入等の別の方面から研究を行なわねばならないと洘 えている、とにかく，現在の抆術に拁いて，近管条血管

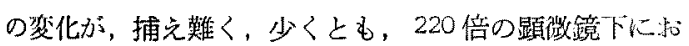
いて, 自律神程毒投与時に特徽的な变化が認められない とするならば，血管の透過性や，直径の变動を部门゙る埸

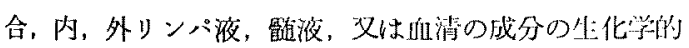
分析の方が，上り感度が鋭敏であり，病態の指䉂として の価值も高いことになる。

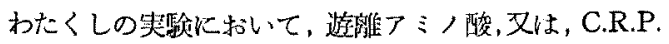
か，血管より，内，外リンパ液中に透消したとすると， 口盖刺激や，ピロカルピン投与洔には，少くとも，これ らの血管の拹張が起つているはずである。しかしこの搪

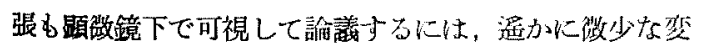
化であろう。

\section{第 VI章 結 語}

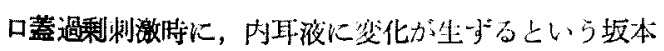

の砳究を発展させ，以下の奏鈳を行つた。

1）過剩刺激時に，外リンパ液に生ずる 4 䅜のアミ， 酸，あるいは C.R.P.を，自律神㹩遮䉼昘たる $\mathrm{C}_{6}$ に上 り阻止した。

2）自律神経毒を投与して，C.R.P. の出現を歓察， エピナミン投与では 6 例中1例に，触液中，又，ピ口力 ルピン投与にては10 例中 5 例に血清 C.R.P. の出現を 見た。

3）モルモットにアナフイラキシーショック，又は， ヒスタミンショックを生ぜしめ, フナフイラキシー時に は，8例中 4 例に，又ヒスタミンショック時には，9例 中 4 例に C.R.P. の出兒を見た。

以上の奉输にて，口蓋刺湤，アナフイラキシーショッ

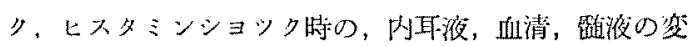

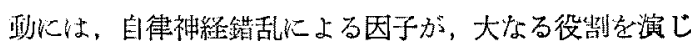
ているむのと推論した，更にこの錯乱状態を，内取螖牛 尚流の生体観察により追究した。

\section{主要參考文献}

1) Atkinson M.: Arch. Otolaryngo. Chicago, 58, 127, 1953. 2) Chevance L.G.: Acta Otolaryngo., 49: 509, 1958.3 3) Chevance L.G.: Acta Otolary. ngo, 50:37, 1959. 4) Chevance L.G.: Galli, A.

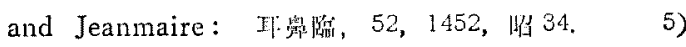
Chevance L.G. et al: Annales d'Oto-Laryngo., 73: 772 , 1957. 6) Chevance L.G. et al: Annales

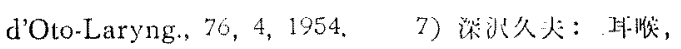
30, 1969, 将33. 8) Fourcade M.: Revue de O. R.L., janvier 114, 1964.

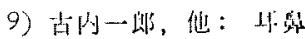

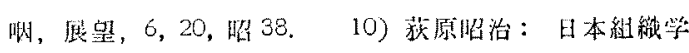
記䥇, 24, 187, 1963. 11) Haaris, H.D. et al: Méd. Clin. North. America: 24, 538, 1940.

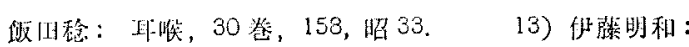

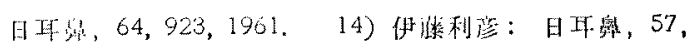

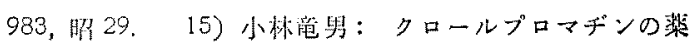
堽, 日仏医学, 2, 119, 1955. 16) Yasuya Nomura: Annales of O.R.L. vol. 70, 81, 1961. 17) Laboriot, H.: (山口, 他訳) Réaction organique à l'agression et choc, 1955. 18) 松生篓治：日佯奥，60，502，昭32. 19) Mygind. S.H.: Acta Oto-laryngol, Suppl. 68: 80, 1948. 20) 三宅弘：日耳異，56，907，昭 28.

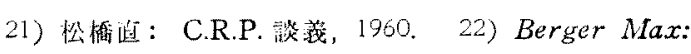
Revue de Laryng-Otolog-Rhinologie, 10, 925, 1962.

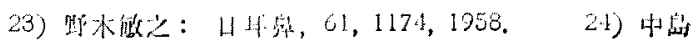




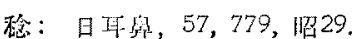

25）永濒邦逤：日耳

舁，61,9,1480, 昭33年. 26) 大野文朗：日耳與， 63, 56, 昭35年. 27) Perlemann, Kimura: Annals of O.R.L. vol. 70, 81, 1961.

28) Perlman H.B.

Kimura R.S.: Annals of O.R.L. 64, 1955.

Reilly J. Rivalier E: Ann. de Méd, avril 333, 1930. 30) Ld (2e Mêmoire)," Ann. de Méd., déc. 524, 1930. 31) Reilly, J., Rivallier E., Compagno A.i C.R. Soc. de Biol., 5 mai 116, 24, 1934. 32) Reilly J. Rivallier E. Compagnon A.: Ann. de Méd. Levrier 39, 165, 1936.

33) Smith

C.A.. Laryngoscope, 61: 1079, 1951.

34) 鎑术方

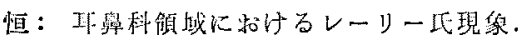

35) 㺘

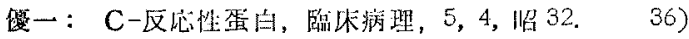

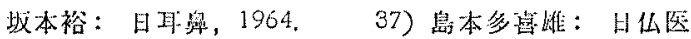
兴, 2, 140, 1955. 38) Speransky A.D.: A basis for theory of medicine 1943, 39) Selye. H.: (田

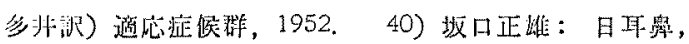

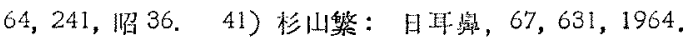

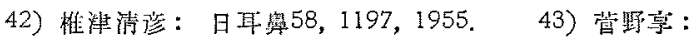
日耳鼠総会雑誌，32, 1964.

44) Tillet, W.S.:

Francis T. ä J. exp. Méd., 52:561, 1930. 45) 支

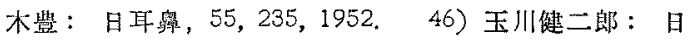

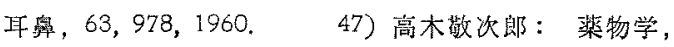
168, 1963.48) 田村造通：耳渎，318，1959.49) 㨁草奏：クロールブロマジンのショツク抑制作用，日 仏医学，2，125，195.50) 牛場大蔵：細菌学入門， 77, 昭30年. 51) Waltner, J.G. and Raymond, S.: Laryngoscope, 60, 912, 1950. 52) Wittmaack, K.: Arch. ohr-usw. Heilk, 117, 241, 1928. 53)

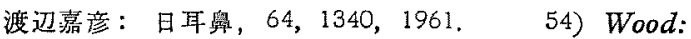

M. Me Carty, R.T. Slater: J. Expel. Méd. 100, 1, 1954. 55) Williams. H.L.: Ann. Otol. Rhinol, S. Lou is 53,397, 1944. 56) 山口踒：日耳会報，64，

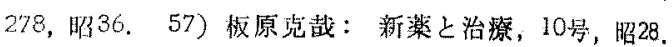

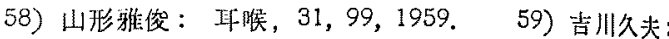
日耳夓，58，696，1955。60) 山口与市：“Reilly 氏 現象”，掫新医学，10，158，明30，61）山口与市：最

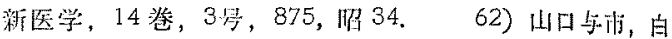

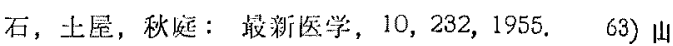

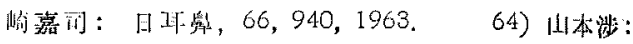

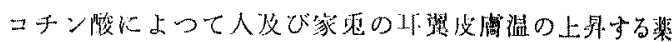
跑について. 65) Siebenmann, F: Die Blutgefesse im labyrinthe des menslichen Ohres. Wresbaden: J. Bergmann, 1894. 66) Agazzi, C: Arch. ital. diotol, 60:40 1949. 67) Nabeya: Acta Suholae med, 6: 1〜132, 1923. 68) 新城之介: ニコチン䣲

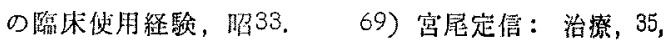

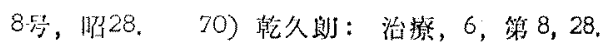

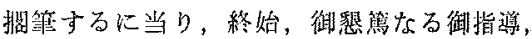

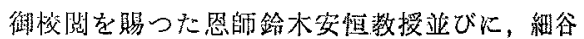

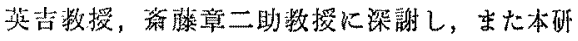
它に際し，军験の場を与え，また常に一方なら 御教示を睗つた㦄大医学部楽理学教室教室買 諸氏に心から深謝致します

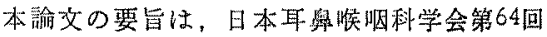

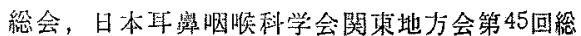
会に括いて発裴した。

(原絾到着 $=$ 昭和 39.6 .18 日一急載) 